Endorphins および Substance P の変動

\author{
中野忍* \\ 新村敦渡辺嘉彦松本勲池園悦太郎
}

要旨：針鎮痛と内因性鎮痛物質との関係を調べる目的で，産婦人科的下腹部疾 患を有する 12 人の患者の麻酔をテトラカインによる持続腰髄麻酔で行った。 8 例において術中両手の合谷に針を刺し，「得気」で長時間（50１20分）通電し， 残り 4 例では針を使用せず，手術前・後おのおのにおいて腰部より脳脊髄液 (CSF) $5 \mathrm{ml}$ を採取し, 含有される Endorphins, Substance P を Radio-immunoassay (RIA) で測定比較した。その結果，針通電により腰部 CSF 中 Endorphins 含量は有意に上昇し, Substance P は減少する傾向にあることが明ら かとなった。

\section{緒 言}

針通電が除痛効果を持つことは古くから知られ ているが，その鎮痛機構はいまだに解明されてい ない。針通電の作用機序を考察するために、針通 電の鎮痛作用を薬物による全身麻酔，局所麻酔と 比較してみると，以下のような特徵を針通電が有 していることがわかる。

1)針通電による鎮痛は，15２0分の通電後に やっと出現し, 通電部位と鎮痛部位との間には, 脊髄分節皮膚支配関係があてはまらないこともし ばしばみられる。

2)はっきりした意識をもった状態で痛覚のみが 減退し，他の知覚は存在する。

3) 通電終了後も鎮痛効果は長く持続する。

4) 通電条件は, 筋収縮をきたす程度の筋刺激が 有効である1。

※ Shinobu Nakano. 東京医科歯科大学医学部麻酔学教室

共同研究者; Atsushi Niimura. Yoshihiko Watanabe. Isao Matsumoto. Etsutaro Ikezono. 東京医科歯科大学医 学部麻酔学教室

Key Words ; Electroacaupuncture, $\beta$-Endorphin, Substance P, Human lumbar C.S.F., Large Intestine Meridian-IV
このような特徵を持つ針通電による鎮痛が麻薬 の拮抗剤である十ロキソン (naloxone) の投与で 消失することが最近報告された ${ }^{2)}$ 。ほぼ時期を同じ くして脳内の特定の部位を電気刺激することに よって得られる鎮痛効果 (SPA; Stimulation Produced Analgesia）がナロキソンで同様に消失 することが報告され す $^{3)}$ SPA と針鎮痛の類似性が 指摘されるに至る。そして SPAにより CSF 中の 内因性鎮痛物質である Endorphins, Enkephalins 濃度が上昇していることが明らかとなると年, こ れら内因性鎮痛物質と針鎮痛の関係が追求される ようになった。そこで今回われわれは，人間にお いて針通電が腰部 CSF 中 Endorphinsにどのよ うな変化をもたらすかを検討することとした。ま た同時に，脊髄後根より入る第一次知覚神経細胞 の伝達物質であり，痛覚の伝達に関与すると考之 られている Substance Pに関してどのような影 響を針通電が及ぼすかを観察した。

\section{方 法}

産婦人科的下腹部疾患のため手術をうけなけれ ばならない 12 人の患者の麻酔をテトラカインを用 いた持続腰髄麻酔で行い, 下半身のみが無痛とな るように鎮痛領域を設定し，有意識下に手術を 行った(図 1 )。腰部 $\mathrm{L}_{3-4}$ または $\mathrm{L}_{4-5} よ り T u o h y$ 針で穿刺し, カテーテルをクモ膜下腔に $5 \sim 10 \mathrm{~cm}$ 
上方に向って挿入し，各症例において穿刺時に手 術前の CSF $5 \mathrm{ml}$ を採取した。採取に用いた Tu ohy 針と注射器, 試験管等はすべてシリコン処理 してあるものを使用した。前投薬は，硫酸アトロ ピン $0.01 \mathrm{mg} / \mathrm{kg}$ ，セコバルビタール $2 \mathrm{mg} / \mathrm{kg}$ で行 い，麻酔の維持はテトラカイン $20 \mathrm{mg}$ を $10 \%$ ブドウ 糖液 $4 \mathrm{ml}$ で溶解させた高比重液とテトラカイン 20

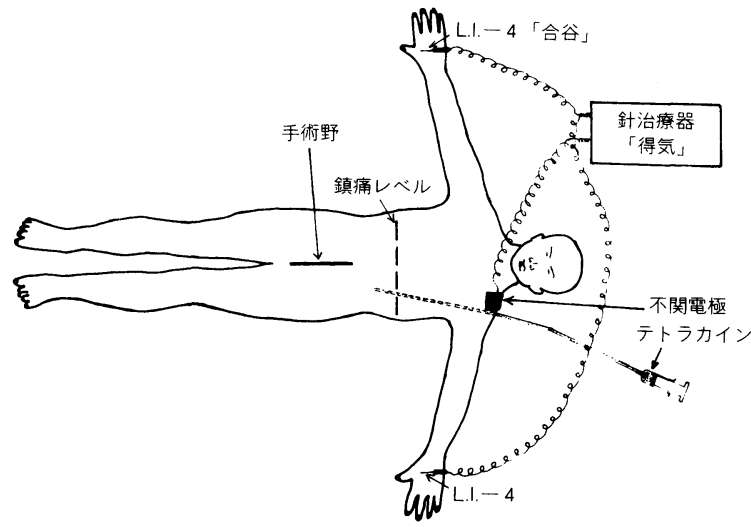

図 1 持続腰值麻酔下での針通電

$\mathrm{mg}$ を $20 \mathrm{ml}$ の蒸留水で溶解させた低比重液を体位に より使いわけて行い, 術中低血圧に対しては plasma expanderの輸液と, 必要に応じて昇圧剂 (工 フェドリン）の筋注・静注を行った。患者の年令 は22〜 52才，体重は36～60kgの間である。

8 例において手術開始直後より両手の合谷 (Large Intestine Meridian-IV) に針を刺し，不 関電極を左肩の後部に設置して針治療器「得気」 で3 C $/ \mathrm{S} ， 1.0 \mathrm{~mA}$ の電流を手術中長時間（50〜1 20 分）にわたり通電し，これを針通電群とした。 一方残り 4 例においては，術中に針は使用せず, これを非通電群とした。手術終了時に, 全例カテー テルより CSF $5 \mathrm{ml}$ を採取した後, カテーテルを 硬膜外腔まで引きもどし，生理食塩水 $0 \sim 40 \mathrm{ml}$ 注入して髄液漏出による頭痛に対処した（表 1 ）。 針通電前・後に採取した CSF は分注後直ちに 超低温 $\left(-80^{\circ} \mathrm{C}\right)$ に冷却保存した。測定は Endorphins, Substance P ともに RIA 法を用い duplicateで行った。Endorphins 測定はN E N 社製 Endorphin 測定 Kit を使用した。RIA 法で常に問 題となるのは，使用した抗体が類似物と反応する 交叉反応である。特に $\beta$-Endorphin $(61-93)$ は,

\section{表 1 持繶腰轋麻酔下での針通電}

人数: 針通電群 $(n=8)$ 非通電群 $(\mathrm{n}=4)$

計12名

年令 : 22 52才

体重: $36 \sim 60 \mathrm{~kg}$

持続腰髄麻酔： $\mathrm{L}_{3} \sim 4$ あるいは $\mathrm{L}_{4} \sim 5$ より穿刺

上向きに $5 \sim 10 \mathrm{~cm}$ チューブ拥入

テトラカイン 綕使用量 $13 \sim 29 \mathrm{mg}$

鎮痛領域 $\mathrm{Th}_{2} \sim \mathrm{Th}_{6}$ 以下

術後硬膜外腔への生食注入量 $0 \sim 40 \mathrm{~m} \ell$

針通電：両手の合谷(L.I.-4)に刺入

左肩の後部に不関電極

$3 \mathrm{c} / \mathrm{s}, 1.0 \mathrm{~mA}, 50 \sim 120$ 分間通電

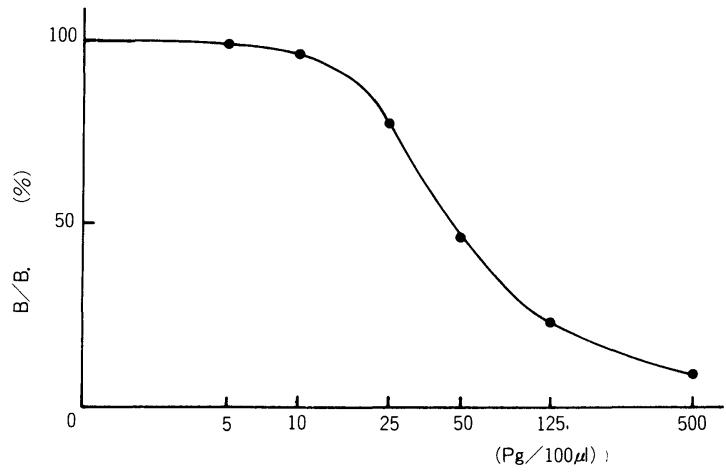

図 $2 \beta$-Endorphin RIAA の標準曲線

$\beta$-LPH $(1$-93)の部分構造であり, $\beta$-Endorphin に特異的に結合し， $\beta$ - LPH と反応しない抗体を 作成することは難しい。今回使用した抗体は $\beta$ $\mathrm{LPH}$ との交叉反応率が50\%である。図 2 に測定 に使用した $\beta$-Endorphin RIA の標準曲線を示す。 RIA 法による最小検出限界は Endorphin, Substance $\mathrm{P}$ ともに $10 \mathrm{pg} / \mathrm{ml}$ である。

\section{結 果}

針通電群 8 例中 7 例において針通電前よりも針 通電後の方が CSF 中 Endorphins は増加してい た。針通電群の腰部 CSF 中 Endorphins 含量は手 術前が101士27 (pg/ml), 通電後が113 $\pm 30(\mathrm{pg} /$ $\mathrm{ml}$ ) である。針通電により CSF 中 Endorphins が 增加しなかった 1 例は, 針通電終了後 5 時間 20 分 後にCSF を採取したもので，他の増加した 7 例 は通電終了後 $5 \sim 15$ 分以内に CSF を採取してい 
る。一方非通電群では，4例とも手術前に比べて 手術後の方が CSF 中 Endorphins は50〜 75\%に 減少していることが明らかとなった。非通電群の Endorphins 含量は, 手術前が $104 \pm 3(\mathrm{pg} / \mathrm{ml})$,

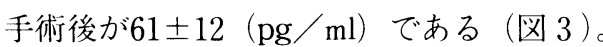

そこで手術前と手術後の CSF 中 Endorphins
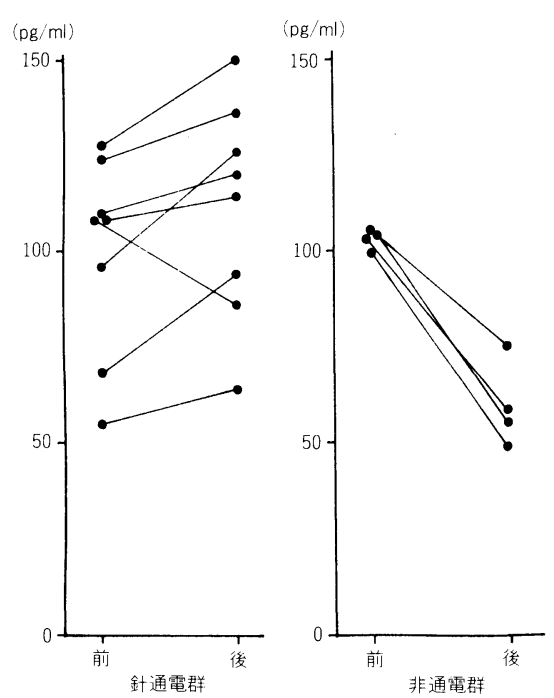

図 3 術前・後に採取した腰部 CSF 中Endorphinsの変動

\begin{tabular}{|c|c|c|}
\hline \multirow[t]{2}{*}{ 表 2} & \multicolumn{2}{|c|}{ 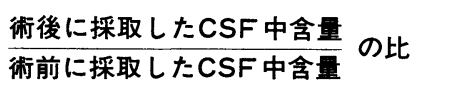 } \\
\hline & 針通電群 & 非通電群 \\
\hline Endorphins* & $\begin{array}{c}1.13 \pm 0.18 \\
(n=8)\end{array}$ & $\begin{array}{r}0.59 \pm 0.11 \\
(n=4)\end{array}$ \\
\hline Substance $\mathrm{P}$ & $\begin{array}{r}0.61 \pm 0.42 \\
(n=3)\end{array}$ & $\begin{array}{r}0.88 \pm 0.21 \\
(n=4)\end{array}$ \\
\hline
\end{tabular}

含有量の比（手術後／手術前）をとり，針通電群 と非通電群を比較したところ，針通電群は $1.13 \pm$ 0.18 , 非通電群では $0.59 \pm 0.11$ と針通電により腰 部 CSF 中 Endorphins は有意に上昇 $(\mathrm{p}<0.001)$ していることが明らかとなった。また同様に Substance Pについても針通電群 3 例, 非通電群 4 例 において CSF 中含有の手術前・後の比を比較し たところ針通電群で $0.61 \pm 0.42$, 非通電群で 0 . $88 \pm 0.21$ であり, 針通電による若干の減少傾向が
みられるものの統計学的有意差はみいだされな かった（表 2 )。

\section{考察およびまとめ}

針鎮痛と SPA との間には，

(1) naloxone でのその鎮痛作用が消失する 2,3 。

(2)鎮痛が得られた時 CSF 中 Endorphins 含量が 增加する ${ }^{4,13)}$ 。

(3)下行性抑制系の起始核（例えばセロトニン 二ューロンの起始核である縫線核）の破壊でその 鎮痛作用が消失する ${ }^{15)}$ 。

(4)下行性抑制線維の通過する脊髄後側索の切断で 鎮痛効果が消失する ${ }^{12) 。 ~}$

など，数多くの類似点が報告されている。また 脳内の Endorphin neuronの分布は，あたかもこ の下行性抑制系に密接に関係しているような走行 を示している14)。これのことは Endorphins ま たは Enkephalins を介して下行性抑制系が賦活 され鎮痛が引き起こされることを示唆するもので ある。さらに内因性鎮痛物質である $\beta$-Endorphin は，下垂体・視床下部に多く存在することが知ら れている6)。脳内に含まれる $\beta$-Endorphin は, 下垂 体切除や8,9)下垂体機能低下症患者でもあまり活性 が低下しないこと7などから脳内各部位で産生さ れたものに由来すると推測される。CSF 中に含ま れる Endorphins は，これら中枢神経内の Endorphin neuronの活動を反映するものと考えられ る。今回の実験で針通電により CSF 中 Endorphinsが増加することがわかったが，これは針通 電によりなんらかの回路をへて Endorphins が放 出されることを示唆するものである。しかし，今 回 $\beta$-Endorphin の測定に使用した RIAの抗体は $\beta-\mathrm{LPH}$ とも交叉するため, どちらが増加してい るのかは不明である。分離には Sephadex G-100 や Biogel P-60 を用いたゲルロ過法が用いられる が10,11)，5 $\mathrm{ml}$ の CSF より Endorphins と Substance $\mathrm{P}$ をduplicate で測定し，さらに $\beta$-Endorphin と $\beta$-LPH を分離するのは量的に不可能で, 新しい分離法を開発するか, $\beta$-LPH と交叉反応 の非常に少ない $\beta$-Endorphin 抗体を使用する必 要がある。また術中にエフェドリンを使用した症 例もあるが，使用の有無は腰部 CSF 中 Endorphins 含量にはあまり影響を与えなかった。非通電 
群において手術前と手術後を比べると，手術後は 著明に Endorphins 含量は減少しており，低比重 液使用による CSF の希釈が起っていることが考 えられる。

第一次知覚神経細胞の伝達物質である Substance P は, 針通電群, 非通電群共に減少傾向にあ り著明な差はみられない。またその個体によるバ ラツキも大きく, 針通電の効果なのか, 局麻剂の 希釈によるものなのか, 局麻剂による鎮痛作用に より痛覚伝達が遮断されるためなのか，その含有 量減少の原因はサンプル数も少ないためはっきり としない。

持続腰髄麻酔では, CSF 漏出による術後の頭 痛, 嘔吐も問題であり, 今後方法論においても改 善をしていくつもりである。

\section{引用文献}

1) Takeshige, C., Luo, C.P., Kamada, Y. : Advanc. in Pain Res. and Therap., I, 781, 1976

2) Mayer, D.J., Price, D.D., Rafe, A. : Antagonism of acupuncture analgesia in man by the narcotic antagonist naloxone. Brain Research, 121, 368, 1977

3) Huda Akil, D.J. Mayer, J.C. Liebeskind, et al. : Antagonism of stimulation produced analgesia by naloxone, a narcotic antagonist, Science, 191, 961-962, 1976

4) Huda Akil, D.E. Richardson, John Hughes, et al. : Enkephalin-like material elevated in ventricular CS F of pain patients after analgesic focal stimulation, Science, 201, 463-465, 1978

5) Huda Akil, D.E. Richardson, J.D. Barchas, et al. : Appearance of $\beta$-endorphin-like immunoreactivity in human ventricular CSF upon analgesic electrical stimulation. Proc. Natl. Acad. Sci. USA, 75, 5170-5172, 1978
6) Nakanishi, S., A.Inoue, T. Kita, M. Nakamura, et al.: Nucleotide sequence of cloned c-DNA for bovine corticotropin- $\beta$-lipotropin precursor, Nature, 278, 423-427, 1979

7) W.J. Jeffcoated, Lesley H. Rees : $\beta$-Endorphin in human CSF,Lancet, 2,119-121, 1978

8) J. Rossier, T.M. Vargo, S. Minick, et al. : Regional dissociation of $\beta$-endorphin and enkephalin contents in rat brain and pituitary, Proc. Natl. Acad. Sci. USA, 74, 5162-5165, 1977

9) J.S. Hong, H.Y.T. Yang, W. Fratta, et al.: Determination of rat brain, Brain Research, 134, 383-386, 1977

10) Yoshikatsu Nakai, Kazuwa Nakao, Shogo Oki, et al. : Presence of immunoreactive $\beta$-lipotropin and $\beta$-endorphin in human placenta, Life Sciences, 23, 2013-2018, 1978

11) Yoshikatsu Nakai, Kazuwa Nakao, Shogo Oki, et al. : Presesce of immunoreactive $\beta$-endorphin in plasma of patients with nelson's syndrome and addison's disease, Life Sciences, 23, 22932298, 1978

12) A.T. Basbaum, et al.: Reversal of morphine and stimu lation-produced-analgesia by subtotal spinal cord lesions, Pain, 3, 43, 1977

13) B. Sjolund, L. Terenius, M. Eriksson : Increased cerebrospinal fluid levels of endorphins after electro-acu puncture. Acta Physiol. Scand., 100, 382, 1977

14) J.D. Barchas, Huda Akil, G.R. Elliott, et al. : Behaviral neurochemistry: Neuroregulator and behavioral states, Science, 200, 964-973, 1978

15) H.K. Proudfit, E.G. Anderson : Morphin analgesia : blockade by raphe magnus lesions, Brain Res., 98, 612-618, 1975

（テ113 文京区湯島 1-5-45 東京医科歯科大学医学部麻酔学教室) 


\title{
Effects of Electroacupuncture on the Levels of Endorphins and Substance P in Lumbar CSF
}

\author{
Shinobu Nakano, Atsushi Niimura, Yoshihiko Watanabe, Isao Matsumoto, Etsutaro Ikezono
}

Tokyo Medical and Dental University, Dept. of Medicine, Anesthesiology

The pain eliminating effects of electroacupuncture have long been known however the analgesic mechanism involved has yet to be clarified. Recently with the discovery of endogenous analgesic peptids called endorphins much attention has been called to the relationship of these endorphins and the acupuncture analgesic effect. We examined to determine how electroacupuncture influences lumbar CSF endorphins and the so-called pain transmitting substance, Substance P.

In order to establish continuous lumbar anesthesia using tetracaine for 8 patients with gynecological lower abdominal diseases, a Tuohy needle was inserted from the lumbar area and a catheter inserted into the subarachnoidal space. In each case at the time of the insertion of the catheter $5 \mathrm{ml}$. CSF was tapped. As pre-medication $0.01 \mathrm{mg} / \mathrm{kg}$. atropine sulfate, $2 \mathrm{mg} / \mathrm{kg}$ secobarbiturate were administered. To maintain the analgesic effect hyperbaric or hypobaric tetracaine was administered according to individaul needs. For hypotension during the operations a plasma expander and when necessary ephedrine were administered by intramuscular or intravenous injection.

Immediately following the start of surgery acupuncture needles were inserted at right and left LI-4 and electrical stimulation at $3 \mathrm{c} / \mathrm{s}, 1.0 \mathrm{~mA}$ was administered for $50-120$ minutes using the acupuncture therapy apparatus "TOKKI". When the operation was finished, after $5 \mathrm{ml}$. of CSF was again tapped through the catheter, the catheter was withdrawn as far as the subdural space and 20 $40 \mathrm{ml}$. physiological saline injected to combat the headache due to spinal fluid leakage. The test substance was immediately transferred to a siliconized test tube and cooled to a temperature of $80^{\circ} \mathrm{C}$.

The RIA methods were used for the measurement of both endorphins and substance $\mathrm{P}$. The crossover reaction between the $\beta$-endorphin and the $\beta \mathrm{LPH}$ was $50 \%$. (Using the $\beta$-endorphin measuring kit manufactured by NEN).

The results in 7 of 8 examples showed a significant increase in CSF endorphins after electroacupuncture. It also became clear that there was a tendency for substance $\mathrm{P}$ levels to decrease due to electroacupuncture. 